\title{
TANITMA 1 / BOOK REVIEW 1: Schluessel, Eric (2018). An Introduction to Chaghatay: A Graded Textbook for Reading Central Asian Sources. Maize Books, Michigan Publishing, ISBN:9781607854951
}

MeqSud SELIM1

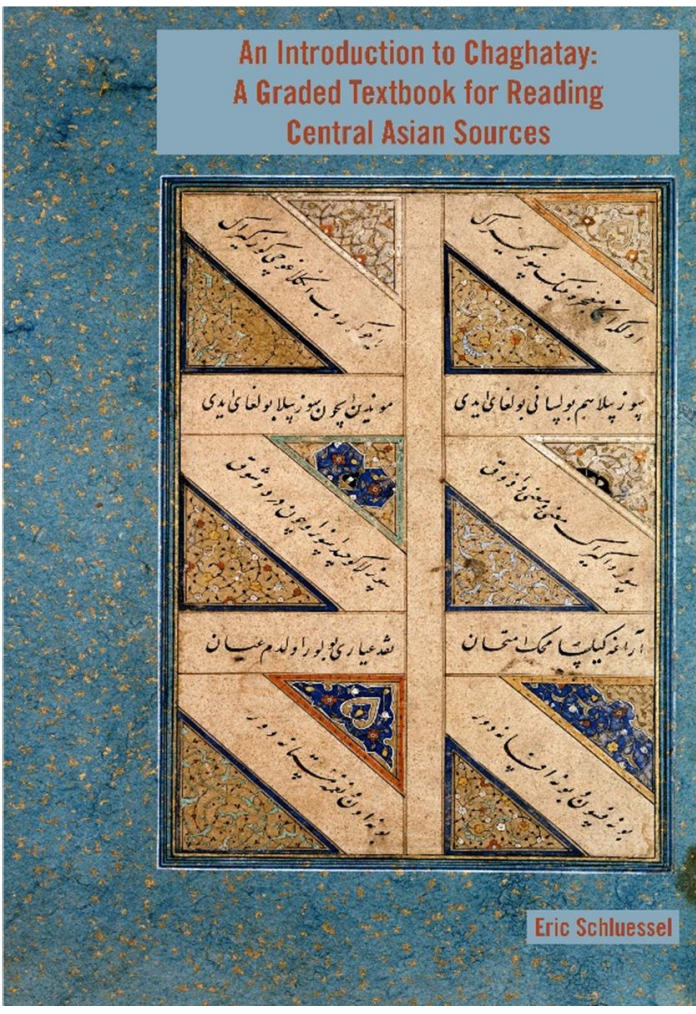

Eric Schluessel published a teaching resource for Chaghatay in 2018, which teaches Chaghatay from the very beginning. This is great news for researchers of history and culture in Central Asia and Xinjiang. Chaghatay has an important place in the study of ancient Asian literature in Central Asia; there are a large number of Chaghatay manuscripts in the Central Asian collection of ancient Asian manuscripts. Therefore, studying Chaghatay is an important way to study various fields in Central Asia. So far, several Chaghatay language teaching resources in Uyghur have been published in China, and there are several textbooks and research texts in Turkey. However, many scholars or enthusiasts may not be able to use these textbooks for language reasons. Schluessel's English textbook is the first to teach the Chaghatay language from very beginning. I will discuss this book in terms of language teaching, phonology, vocabulary, etc.

This textbook has 287 Pages and 16 lessons. The beginning of the book first introduces Chaghatay terminology, and provides common reference books. Then, there is a stage of recognizing the alphabet, which includes examples of letters, writing, phonetics and the harmony system. After this comes the first teaching unit. The units are arranged in order according to their difficulty, with each unit composed of basic vocabulary, grammar points and exercises. There is a relatively simple original text for reading practice after almost every lesson. Therefore, I believe it is a good textbook for learning the Chaghatay language.

In the foreword, the author introduces in detail how to write Chaghatay terms in English. This part also introduces the word "Chaghatay" used by the author after mentioning Chagatay, Chaghatay, Chagatai and other spellings. Besides the term Chaghatay, there are Chaghatay, Chaghatay Uygur, ancient Uzbek, Chaghatay Turkish and other names all over the world; there are different terms and different spellings of the word in books and articles published in different countries or regions. This book clearly puts forward and supports the spelling of Chaghatay and the use of this term in standard English. Therefore, it is of great significance to discuss this problem in this teaching book.

The teaching book teaches Chaghatay from the very beginning. Books such as Chagatay Manual (Eckmann, János. 1966) and A Grammer of Chagatay (Bodrogligeti, András J. E. 2001) related to

1 Doç. Dr., Kuzeybatı Milliyetler Üniversitesi, Azınlık Milliyetler Dili ve Edebiyatı Fakültesi (Lanzhou, Çin), meqsudselim@hotmail.com, ORCID ID: oooo-0002-1600-1716 [Makale kayt tarihi: 01.06.2020-kabul tarihi: 20.06.220; DOI: 10.29000/rumelide.753338] 
Chaghatay, published before this period, are more suitable for language researchers in Chaghatay, which is difficult for zero-based learners. This book also discusses and analyzes various language problems in Chaghatay. It focuses on Chaghatay learning for zero-based students or scholars, thereby starting to teach with the most basic letters at the beginning. In addition, each letter is marked with a reading method as well as the computer input and handwriting of the letter. Therefore, students can become familiar with the handwriting of each letter when starting to learn. It is usually easy for scholars to recognize each letter and its different spellings when interpreting manuscripts. However, the most common problem in Chaghatay manuscripts is that some of the letters cannot be recognized. Therefore, this book shows the way each letter is written and gives examples, which helps to solve the problem that the letter cannot be recognized in a manuscript. In addition, the textbook has practice in reading computer input Chaghatay text after each lesson; this method has not been used in a Chaghatay textbook before, and it is very helpful to the students.

This teaching text further explains problems in phonetics and transcription, and the methods in this book are based on previous research results. Moreover, the problems of front vowel (i), back vowel (i) and natural vowel (e) in Chaghatay are also explained and analyzed in details. As mentioned in the book, I think the vowel system in Chaghatay must be generally consistent with that in Old Uyghur. It is necessary to distinguish the front vowels and back vowels during language research.

This book is the first English teaching resource based on Xinjiang Chaghatay literature. As we all know, Chaghatay literature is widely distributed throughout Central Asia and Xinjiang, China. Previously, scholars were familiar with the books written by János Eckmann, András J. E. Bodrogligeti and other scholars, which mainly introduced and interpreted Chaghatay literature found and collected in Central Asia. However, this book mainly focuses on an introduction to and excerpts from Chaghatay literature related to Xinjiang, which is the first time in the academic world.

Most of the content of the book uses historical Chaghatay documents, which are much simpler as prose than poetry. A considerable proportion of Chaghatay manuscripts are poetry. Therefore, it is a challenge for those without a foundation in Uyghur or Uzbek. This book mainly uses historical documents to help beginners get started more easily.

As the first English teaching resource published for teaching and learning Chaghatay, in my opinion this book also has some disadvantages while having the advantages explained above:

The references can be improved. As a teaching book of Chaghatay for scholars, the foreword provides a bibliography of Chaghatay literature. The references not only include the Jarring's dictionary (Gunnar Jarring, 1964) and other literature which are indispensable in the literature research of Xinjiang Chaghatay, but also the J. W. Redhouse dictionary and other references which are not closely related to literary interpretation. The dictionary is an Ottoman Turkish-English dictionary. Though there are some similarities between Ottoman Turkish and Chaghatay, some differences still exist. Therefore, I think there is still space to expand the references. For example, 1. Burhanı Katı (Mutercim Âsim Efendi, Haz. Mürsel Öztürk, Derya Örs, 2009) 2. Osmanlıca-Türkçe Ansiklopedik Lûgat (Ferit Devellioğlu, 1993) 3. Nevâyı̂’nin Sözleri ve Çağatayca Tanıklar (Mustafa S. Kaçalin, 2011); 4. References such as Chaghatay dictionaries published in China, such as A Grammar of Chaghatay Uyghur (Abdureop Polat, 2007), Dictionary of Chaghatay Uyghur (Hamit Tömür, Abdureop Polat, 2016) and Detailed Explanation Dictionary of Chaghatay (Bahavudun, Muhammettursun. 2002). 
Some words in the glossary should be further studied. There is a common vocabulary of Chaghatay literature in the book, which is helpful for reading and translating the original literature, but some of them need to be studied further, such as taş, yol, patman, ğelbir, çarek.

The writing of some words is inconsistent. There are some inconsistencies in the writing of Uyghur in Chaghatay literature, so some words in this book are also written differently in different places. For example, the word "cow" on Pages 6 and 7 has different writing. I think it is better to keep the general orthography in the teaching material, and the above situations can be explained in the notes, since beginning learners may feel confused when they see a word written in two different ways. Moreover, such phrases or related sentence exercises can directly use the examples in the original literature.

\section{Conclusion}

As the first English-medium teaching material of Chaghatay, the overall structure, content, difficulty and other aspects in this book are very comprehensive and reasonable. Therefore, I think this book is a good teaching resource for zero-based students to learn Chaghatay. As the first English textbook of Chaghatay, it is understandable that there are some shortcomings or imperfections in the content, but they can be revised or supplemented in reprints. The most important thing is the publication. Therefore, I strongly recommend this book to students who are interested in Chaghatay literature. Of course, this book also has a free electronic version for the user.

\section{References}

Bahavudun, Muhammettursun (2002). Çağatay Tilining İzahlıq Luğiti. Ürümçi : Şinjang Helq Neşriyatı.

Bodrogligeti, András J. E. (2001). A Grammer of Chagatay. Lincom Europa.

Devellioğlu, Ferit (1993). Osmanlıca-Türkçe Ansiklopedik Lûgat. İstanbul : Aydın Kitabevi.

Eckmann, Janos (1966). Chagatay Manual. Bloomington : Indiana University.

Kaçalin, Mustafa S. (2011). Niyazi: Nevayinin Sözleri ve Çağatayca Tanıklar. Ankara : Türk Dil Kurumu.

Öztürk, Mürsel; Örs, Derya (2009). Mutercim Âsim Efendi: Burhân-ı Katı. Ankara : Türk Dil Kurumu.

Tömür, Hamit; Polat, Abdureop (2016). Çağatay Uyğur Tilining İzahlıq Luğiti. Beijing : Milletler Neşriyatı. 